\title{
EFFECTS OF PLANT PREPARATIONS OF PURE SAPONINS AND METHOXYFLAVONOIDS ON THE EXPRESSION OF IMMUNE RESPONSE GENES
}

\author{
Turmagambetova A.S., Bogoyavlenskyi A.P., Alexyuk P.G., Alexyuk M.S., \\ Omirtaeva E.S., Sokolova N.S., Zaitseva I.A., Berezin V.E. \\ Research and Production Center for Microbiology and Virology \\ 105, Bogenbai batyr Str., Almaty, 050010, Kazakhstan \\ aichyck@mail.ru
}

\begin{abstract}
Studies on the immunostimulating properties of saponins and methoxyflavonoids obtained from plants provides a theoretical basis for development of new immunopotentiators, thereby increasing effectiveness of immunotherapy and prophylaxis of viral infections. Expression of major genes of the immune response were significantly up-regulated upon introduction of plant-based immunostimulators into the body. These compounds were a mixture of purified saponin betulin isolated from plants of Betula sp. (Betula pendula) and purified methoxyflavonoids of plants of Polygonum sp. (Polygonum persicaria) and Cytrus sp. (Cytrus sinensis). The strength and specificity of the body's immune response can be adjusted by changing the structure of the methoxyflavonoid in the complex immunostimulator, which makes it possible to stimulate targeted immunostimulators that act on certain parts of the immune system.

Keywords: saponin, methoxyflavonoid, immunostimulator, influenza, gene expression.
\end{abstract}

\section{INTRODUCTION}

Plants and preparations of plant origin have long been used to increase the activity of the immune system and restore the immunity. However, there is still no clear understanding of the mechanisms of the immunotropic action of phytopreparations. Most often plant origin immunostimulators are used in the treatment of infectious diseases (influenza, ARVI) and as preventive measures especially during seasonal outbreaks. Modulating the work of immunity they have a beneficial effect on the course of the disease speeding up the healing process and minimizing the possible consequences.

The development of the infectious process occurs against the weakened state of the immune system. Therefore, by stimulating of some branches of the immune system it is possible to increase the overall resistance to viral infections. The study of factors affecting the various stages of the immune response formation and activation of various parts of the immune system is the basis for the development of theories of the immune response during the infectious process. Moreover, studies in this area create theoretical prerequisites for the development of new, more effective immunotherapeutic medicines. The study on the mechanisms of stimulation of specific and general antiviral immunity by biologically active compounds of plant origin aimed at the development of new 
medicines that can increase the resistance of the organism to viral infections is an important problem of fundamental research in virology and immunology, which ultimately increase the effectiveness of not only immunotherapy of viral infections but their vaccination as well. Currently, an intensive study on the mechanisms of activation of innate and specific antiviral immunity and the search for new immunostimulators capable of increasing the activity of the immune response are carried out $[1,2]$.

The aim of the research was to evaluate the effect of complex plant immunostimulators obtained on the basis of various combinations of purified saponin and glycosylated methoxyflavonoids on the expression of the immune response genes.

\section{Materials and methods}

Purified preparations of saponin and methoxyflavonoids (figure 1) were obtained from the aerial parts of the plant Polygonum sp. (isorhamnetin glycoside), bark of the plant Betula sp. (betulin) and the rind of the fruit of the plant Cytrus sp. (hesperetin glycoside) using the method of alcohol extraction, followed by fractionation by highperformance liquid chromatography (HPLC), as described previously [3, 4]. Reference compounds ensured accuracy of isolation.
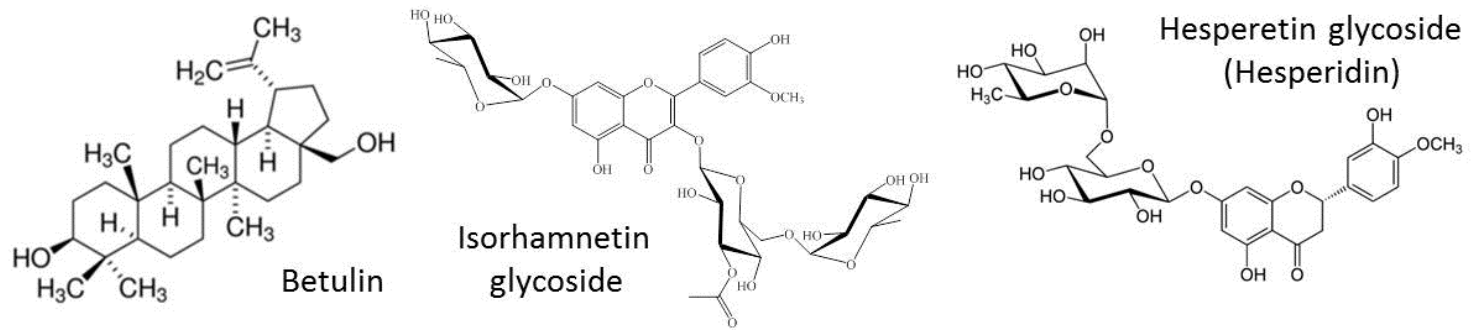

Fig. 1. Purified compounds used in the study

White outbred mice of both sexes weighing 15-25 grams were used in experiments.

Immunization of animals for the proliferation of macrophages. 1-month-old white mice were intraperitoneally injected once with the test preparations at a dose of 100 $\mu \mathrm{g} /$ mouse in the case of methoxyflavonoids and $30 \mu \mathrm{g} /$ mouse in the case of saponin. The amount of injected material was consistent with the recommendations of international organizations and did not exceed $0.2 \mathrm{~mL}$ per animal [5]. The control group of animals was administered phosphate buffered saline (placebo).

Peritoneal macrophages were collected 3 days after administration of test preparations by abdominal cavity lavage with a cooled medium 199. Cells were washed twice and resuspended at a concentration of $2 \times 10^{6}$ cell/mL in a culture medium (medium 199).

The total RNA was isolated using Rneasy Mini Kit (QIAGEN, GmbH, Germany) according to the guidelines.

Reverse transcription was performed using M-MLV (Promega, USA) in $5 \mu \mathrm{L}$ of the reaction mixture $(2.7 \mu \mathrm{L}$ of sample, $0.725 \mu \mathrm{L}$ of water, $1 \mu \mathrm{L}$ of $5 \times$ reverse transcriptase buffer (Promega, USA), $0.2 \mu \mathrm{L}$ of $2 \mathrm{mM}$ dNTP Mix, $0.25 \mu \mathrm{L}$ of $20 \mathrm{OU}$ random primer (9 or 18 nucleotides), and $0.125 \mu \mathrm{L}$ of M-MLV). The reaction was carried out at $37^{\circ} \mathrm{C}$ for 60 minutes.

The real-time polymerase chain reaction (RT-PCR) was carried out in $20 \mu \mathrm{L}$ of the reaction mixture ( $4 \mu \mathrm{L}$ of DNA matrix, $8 \mu \mathrm{L}$ of SybrGreen MasterMix, $1 \mu \mathrm{L}$ of each of $20 \mathrm{OU}$ forward and reverse primers, water). 35 cycles of PCR on the PicoReal thermal cycler were carried out with the following modes: $94^{\circ} \mathrm{C}-1 \mathrm{~min}, 48^{0} \mathrm{C}-1 \mathrm{~min}, 72^{\circ} \mathrm{C}-3$ min. The primer pairs were selected according to the sequence of examined interleukin 
(IL-6, Forward: 5' -cag aat tgc cat cgt aca act ctt ttc tca-3'; Reverse: 5'-aag tgc atc atc gtt gtt cat aca -3'), cytokine (TNF, Forward: 5'-cat ctt ctc aaa att cga gtg aca a-3'; Reverse: 5'-tgg gag tag aca agg tac aac cc -3') and immunoglobulin (IgA: Forward 5'-cca ctc tgt ctt tct ctt cac a-3', Reverse 5'-cac cca gtg cat gta gta gtc-3'; IgG: Forward 5'-cct tga gtg gat tgg aga gat tta-3', Reverse 5'-aga ctg cag agt cct cag at-3'). Normalization of gene expression was performed with the actin gene (Forward: 5'-aga ggg aaa tcg tgc gtg ac3'; Reverse: 5'-caa tag tga tga cct ggc cgt-3').

Statistical processing of the results was carried out using the Microsoft Excel 2010 software package.

\section{RESULTS AND DISCUSSION}

The effect of different combinations of purified saponin (Betulin) obtained from the plant Betula sp. and purified methoxyflavonoids (isorhamnetin glycoside, hesperetin glycoside) obtained from the plants Polygonum sp. and Cytrus sp. on the immune response genes expression was examined.

On the IL-6 and TNF gene models the evaluation of the stimulation of the immune response genes expression was performed at a single intraperitoneal immunization of experimental animals with the combinations of immunostimulator preparations mentioned above. The genes expression level of these cytokines was determined at macrophages collected on the third day after introduction of preparations (figure 2).

It was shown that the expression level of the pro-inflammatory cytokine IL-6 gene increased by $13.7 \log _{2}$ compared with the control group after administration of the mixture of betulin with isorhamnetin glycoside as an immunostimulator, and by 5.8 $\log _{2}$ when betulin was administered to animals in combination with hesperidin; i.e. the combination of betulin with the isorhamnetin glycoside had a much more pronounced activating effect.

The study of changes in the expression level of the TNF gene at the introduction of various combinations of purified saponin and methoxyflavonoids showed (figure 2) that the expression level of this gene increased by $2.8 \mathrm{Log}_{2}$ compared with the control after administration of the experimental animals betulin combined with hesperidin. Apparently, the introduction of the complex preparation of betulin with the isorhamnetin glycoside caused such a strong secretion of IL-6 that TNF secretion was suppressed.

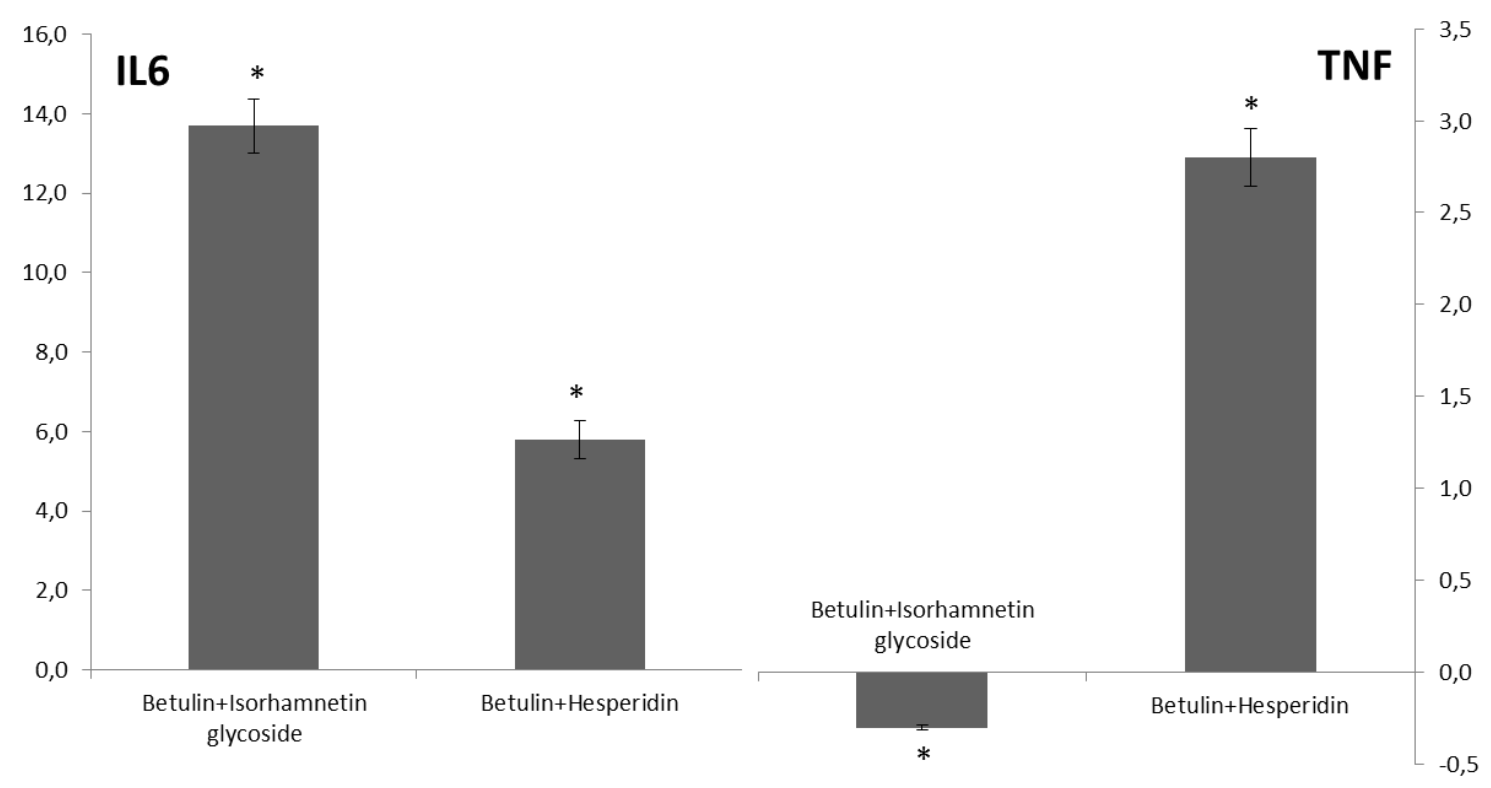


The multiplicity of changes in gene copies is plotted along the y-axis. Combinations of methoxyflavonoids with betulin are shown along the $\mathrm{x}$-axis. Gene expression is shown as the multiplicity of changes in gene copies. The results are presented as the average value from four individual mice. Statistically significant results are shown above the bands as $* \mathrm{p} \leq 0.05$.

Fig. 2. Modulation of IL-6 and TNF gene expression with combinations of immunostimulator preparations containing betulin and methoxyflavonoids

The first phase of interaction of the immunostimulator preparation with the immune system is the initiation of the synthesis of pro-inflammatory cytokines responsible for activation of the mechanisms of restriction and elimination of the lesion focus and pathogenic factors that caused it, as well as the repair of damaged tissues. Pro-inflammatory cytokines cause inflammation mediated by a cascade of gene products (IL-6, TNF, IL-1), which as a rule are not produced in a healthy body. At a significant inflammatory process IL-6 begins to suppress the secretion of TNF and IL-1, and activate the production of the inflammatory acute-phase proteins, which contributes to the regulation of the inflammatory process $[6,7]$. In this sense IL- 6 can be considered as a pro-inflammatory cytokine. It is produced not only by cells of the immune system and auxiliary cells possessing an immune function, but also by the numerous cells that do not have a direct relationship to the immune system [6, 8-10].

Thus, it can be assumed that the activity of the immune response can be significantly increased by introducing into the body the nonspecific plant origin immunostimulator containing saponin in combination with a glycosylated methoxyflavonoid.

In accordance with the task of the study the ability of the combination of immunostimulator preparations to stimulate the expression of immunoglobulin ( $\operatorname{Ig} \mathrm{A}$ and IgG) synthesis genes was modeled. The previously selected combinations of immunostimulator plant preparations were administered intraperitoneally once to the animals. Macrophages were collected from the animals 3 days after the preparations administration and the level of immunoglobulin ( $\operatorname{IgA}$ and $\operatorname{IgG}$ ) genes expression was determined (figure 3).

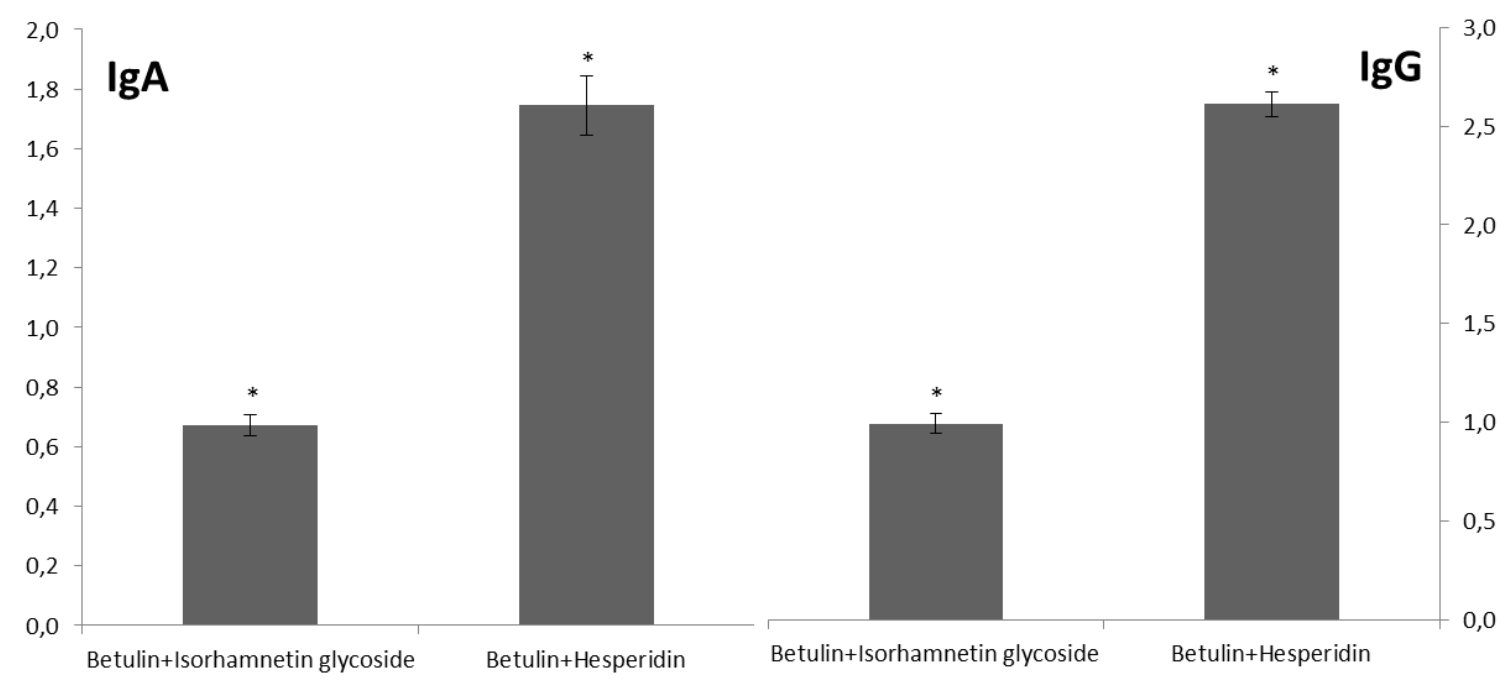

The multiplicity of changes in gene copies is plotted along the $y$-axis. Combinations of methoxyflavonoids with betulin are shown along the $\mathrm{x}$-axis. Gene expression is shown as the multiplicity of changes in gene copies. The results are presented as the average value from four individual mice. Statistically significant results are shown above the bands as $* p \leq 0.05$.

Fig. 3. Modulation of $\operatorname{IgA}$ and $\operatorname{IgG}$ gene expression with combinations of immunostimulator preparations containing betulin and methoxyflavonoids 
It was shown that the level of IgA gene expression increased by $1.7 \log _{2}$ compared with the control group by the administration to experimental animals the composition betulin-hesperidin. In the case of using the combination of betulin with isorhamnetin glycoside as an immunostimulator the expression level of the studied gene increased only by $0.7 \log _{2}$ in comparison with the control group.

It was found that the expression level of the $\operatorname{IgG}$ gene increased compared with the control by $2.6 \log _{2}$ by the introduction the composition of betulin-hesperidin as an immunostimulator and by $1.0 \log _{2}$ in comparison with the control group at the introduction of betulin in combination with isorhamnetin glycoside.

The results show that the stimulation of the immunoglobulin (IgA and $\operatorname{IgG}$ ) genes expression related to specific antiviral immunity genes is more pronounced after administration to animals the betulin in combination with methoxyflavonoid hesperidin.

Thus, as a result of the experiments it was found that the activity of genes expression responsible for the development of specific and nonspecific antiviral immunity may change with a change in the amount of glycosidic residues in the methoxyflavonoid molecule administered in combination with immunostimulating saponin.

\section{CONCLUSION}

According to the results from the studies it was shown that the expression of the main genes of the immune response can be significantly increased by introducing plant origin immunostimulators into the body based on a mixture of purified saponin betulin isolated from the plant Betula sp. and purified methoxyflavonoids of plants Polygonum sp. and Cytrus sp. It is shown that at an unchanged saponin component the amount of glycosidic residues in the composition of methoxyflavonoid molecule affects its biological activity. So the methoxyflavonoid isorhamnetin glycoside which contains three glycosidic residues in the molecule in combination with saponin showed the ability to stimulate the expression of the pro-inflammatory cytokine IL-6 gene so actively that the suppression of the expression of the TNF gene occurred. In model experiments were shown that the stimulation of the $\operatorname{IgA}$ and the $\operatorname{IgG}$ genes expression related to the genes of specific antiviral immunity to a greater degree occurs at administration to animals the plant origin immunostimulator based on a mixture of the purified saponin from the plant Betula $s p$. and the purified methoxyflavonoid containing 2 glycosidic residues from the plant Cytrus $s p$.

Thus, it has been shown that by changing the methoxyflavonoid component of a complex immunostimulator it is possible to regulate the expression of the main genes of the immune response which makes it possible to rely on the creation of targeted immunostimulators that affect certain parts of the immune system.

\section{Acknowledgements}

This work was supported by the Ministry of Education and Science of the Republic of Kazakhstan (grant project AP05130957).

\section{REFERENCES}

1. Son Y.O., Kook S.H., Lee J.C. Glycoproteins and Polysaccharides are the Main Class of Active Constituents Required for Lymphocyte Stimulation and AntigenSpecific Immune Response Induction by Traditional Medicinal Herbal Plants. Journal of Medicinal Food, 2017, https://doi.org/10.1089/jmf.2017.3943. 
2. Wei W., Feng L., Bao W.R. et al. Structure characterization and immunomodulating effects of polysaccharides isolated from Dendrobium officinale. Journal of Agricultural and Food Chemistry, 2016, vol. 64, no. 4, pp. 881-889.

3. Berdimuratova G.D., Muzychkina R.A., Korul'kin D.Ju. i dr. Biologicheski aktivnye veshhestva rastenij: Vydelenie, razdelenie, analiz. [Biologically active substances of plants: isolation, separation, analysis]. Almaty, Atamura Publ., 2006. 438 p.

4. Muzychkina R.A., Korul'kin D.Ju., Abilov Zh.A. Kachestvennyj i kolichestvennyj analiz osnovnyh grupp BAV v lekarstvennom rastitel'nom syr'e i fitopreparatah [Qualitative and quantitative analysis of the main groups of biologically active substances in medicinal raw plant materials and phytopreparations]. Almaty: Qazaq University Publ., 2004. 288 p.

5. Order of the Ministry of Healthcare and Social Development of the Republic of Kazakhstan No. 415, dated May 29, 2015 "Rules for caring out preclinical (non-clinical) studies of biologically active substances, medicines, medical devices and medical equipment".

6. Heinrich P.C., Castell J.V., Andus T. Interleukin-6 and the acute phase response. Biochem J, 1990, vol. 265, pp. 621-636.

7. Lyson K., McCann S.M. The effect of interleukin-6 on pituitary hormone release in vivo and in vitro. Neuroendocrinology, 1991, vol. 54, pp. 262-266.

8. Boockfor F.R., Wang D., Lin T., Nagpal M.L., Spangelo B.L. Interleukin-6 secretion from rat Leydig cells in culture. Endocrinology, 1994, vol. 134, pp. 21502155.

9. McGee D.W., Beagley K.W., Aicher W.K., McGhee J.R. Transforming growth factor-beta and IL-1 beta act in synergy to enhance IL-6 secretion by the intestinal epithelial cell line, IEC-6. J Immunol, 1993, vol. 151, pp. 970-978.

10. Bellido T., Stahl N., Farruggella T.J., et. al. Detection of receptors for interleukin-6, interleukin-11, leukemia inhibitory factor, oncostatin $\mathrm{M}$, and ciliary neurotrophic factor in bone marrow stromal/osteoblastic cells. J Clin Invest, 1996, vol. 97, pp. 431-437. 


\title{
ТАЗАРТЫЛҒАН САПОНИН ЖӘНЕ МЕТОКСИФЛАВОНОИД НЕГІЗІНДЕГІ КЕШЕНДІ ӨСІМДІК ПРЕПАРАТТАРЫНЫН ИММУНДЫ ЖАУАПТЫН ЭКСПРЕССИЯ ГЕНІНЕ ӘСЕРІ
}

Турмагамбетова А.С., Богоявленский А.П., Алексюк П.Г., Алексюк М.С., Омиртаева Э.С., Соколова Н.С., Зайцева И.А., Березин В.Э.

\author{
Микробиология және вирусология гыльлми-өндірістік орталывы \\ 105, Богенбай батыр к., Алматы к., 050010, Қазақсттан \\ aichyck@mail.ru
}

\section{ТYЙІН}

Әртүрлі түр өсімдік қосылыстары (сапониндер, метоксифлавоноидтары) негізінде алынған композициялардың иммунды ынталандырушы қосылыстардың қасиеттерін зерттеу, вирусты жұқпалардың иммунды алдын алуын және иммунды терапияның белсенділігін жоғарлатуға мүмкіндік тудыратын жаңа әсерлі иммунды потенциаторларды жасауға теориялық алғышарттар береді. Жүргізілген зерттеу нәтижелері иммунды жауап гендерінің белсендірілуі, өсімдік текті ағзаға тән емес кешенді иммунды ынталандырушыларды ағзаға енгізу арқылы көбейтуге болатынын көрсетті. Ағза иммунды жауабының арнайлығын және күшін, кұрама иммунды ынталандырушыда метоксифлавоноид құрлымын өзгерту арқылы реттеуге болады, ол өз кезегінде белгілі иммунды жүйенің бөліктеріне әсер беретін таргентті иммунды ынталандырушыларды құруға мүмкіндік тудырады.

Негізгі сөздер: сапонин, метоксифлавоноид, иммунды ынталандырушылар, тұмау, ген экспрессиясы.

\section{ВЛИЯНИЕ КОМПЛЕКСНОГО РАСТИТЕЛЬНОГО ПРЕПАРАТА НА ОСНОВЕ ОЧИЩЕННОГО САПОНИНА И МЕТОКСИФЛАВОНОИДА НА ЭКСПРЕССИЮ ГЕНОВ ИММУННОГО ОТВЕТА}

Турмагамбетова А.С., Богоявленский А.П., Алексюк П.Г., Алексюк М.С., Омиртаева Э.С., Соколова Н.С., Зайщева И.А., Березин В.Э.

Научно-производственный цееттр микробиологии и вирусологии

105, ул. Богенбай батыра, г. Алматы, 050010, Казахстан

aichyck@mail.ru

\section{АБСТРАКТ}

Изучение иммуностимулирующих свойств композиций, полученных на основе растительных соединений разных классов (сапонины, метоксифлавоноиды), дает теоретические предпосылки для разработки новых более эффективных иммунопотенциаторов, позволяющих повышать эффективность иммунотерапии и иммунопрофилактики вирусных инфекций. В результате проведенных исследований показано, что активацию генов иммунного ответа можно значительно повысить путем введения в организм неспецифических комплексных иммуностимуляторов растительного происхождения. Показано, что силу и специфичность 
иммунного ответа организма можно регулировать при изменении структуры метоксифлавоноида в комплексном иммуностимуляторе, что позволяет рассчитывать на создание таргетных иммуностимуляторов, воздействующих на определенные звенья иммунной системы.

Ключевые слова: сапонин, метоксифлавоноид, иммуностимулятор, грипп, экспрессия генов. 
